\title{
Evaluation of the conceptual basis of the rational method
}

\begin{abstract}
It is interpreted in this study that the IUH of the well known rational method corresponds to the time-area concentration curve at the outlet of a symmetrical V-watershed. The appropriateness of this interpolation is verified by simulating a number of hypothetical hydrographs at the outlet of different sizes of area such V-watersheds varying from $0.1 \mathrm{~km}^{2}$ to $1 \mathrm{~km}^{2}$, using kinematic wave theory of the HEC-HMS model, and proving that for increasing intensity of rainfall over a given watershed area, the kinematic wave hydrograph tends to approach the shape of triangular hydrographs, characteristic of the rational method; Similarly, for a given rate of rainfall and for increasing watershed area, the kinematic wave hydrographs tend to deviate away from the triangular hydrograph shape, thus, establishing the appropriateness of the rational method for application to small urban watershed runoff studies not only for peak flood estimation but also for associated distribution of runoff volume.
\end{abstract}

Keywords: rainfall-runoff relationships, kinematic wave theory, urban runoff, hydrographs, rational method
Volume 2 Issue 6 - 2018

\author{
Jainet PJ \\ Scientist, Centre for Water Resources Development and \\ Management, Kozhikode, India
}

\begin{abstract}
Correspondence: Jainet PJ, CWRDM Sub Centre, Neyyattinkara, Trivandrum, India, Tel +9| 47| 22223 I9, Email jaynet@cwrdm.org
\end{abstract}

Received: May 28, 2018 | Published: November 23, 2018

\section{Introduction}

The rational method is one of the most popular runoff estimation methods used for estimating peak runoff $Q p$ required for the design of drainage facilities of small urban watersheds. The rational behind the method is that when a uniform rate of design rainfall is applied over the small watershed for a duration equal to the time of concentration of that watershed, then the runoff rate at the outlet of the watershed is maximum when the entire watershed contributes. ${ }^{1}$ The hydrograph associated with that peak runoff is of the shape of an isosceles triangle with uniform rate of increase of the rising limb upto the time of concentration, $\mathrm{T}_{\mathrm{c}}$ and with same rate of fall on the recession limb. $\mathrm{Nash}^{2}$ reported that based on linear system theory the hydrograph of the rational method can be obtained by convoluting the Instantaneous Unit Hydrograph (IUH) of the rational method with the uniform rainfall intensity of duration Tc. He inferred that the IUH corresponds to that of a rectangular pulse of duration Tc with the uniform intensity ordinate $\mathrm{A} / \mathrm{Tc}$, where $\mathrm{A}$ is the watershed area. $\mathrm{Nash}^{2}$ opined that such a shape of IUH is inconceivable as it is not characteristic of a conventional IUH with an increasing rising limb and a falling limb.

It is interpreted in this paper that the rectangular shape of IUH is conceivable and it corresponds to the IUH of a symmetrical $\mathrm{V}$-watershed of an urban area. To substantiate this interpretation, in this study, a number of hypothetical hydrographs were simulated at the outlet of a such $\mathrm{V}$-watersheds for area varying from $0.1 \mathrm{~km}^{2}$ to 1 $\mathrm{km}^{2}$ using kinematic wave theory option of runoff generation of the HEC-HMS model, ${ }^{3}$ and demonstrating that for increasing intensity of rainfall over a given watershed the kinematic wave hydrograph tends to approach the shape of a triangular hydrograph, characteristic of the rational method; similarly for a given uniform rate of rainfall and for increasing watershed area, the generated kinematic wave hydrographs tend to deviate away from the triangular hydrograph shape, thus, establishing the appropriateness of the rational method for application to small urban watershed runoff studies

\section{Concept procedure used for the evaluation of the rational method}

The rational method may be considered as a conceptual model employed for rainfall-runoff modeling. A conceptual model attempts to simulate the behaviour of the catchment action on the rainfall to convert it to runoff in a simplified form by lumping the distributed action of a real watershed. While in the real runoff process the runoff is generated in a distributed manner by of simultaneous action of translation and attenuation on any small unit of input, the same actions are executed by the conceptual model by two separate actions of translation and attenuation in a lumped manner. As the IUH of the rational method is a rectangular pulse with uniform ordinate of $\mathrm{A} / \mathrm{Tc}$ for a duration of Tc, it may be considered that it represents the timearea diagram at the outlet of the symmetrical V-shaped watershed. Therefore, one may consider that the rational method attempts to simulate the overland flow runoff generation at the outlet of a $\mathrm{V}$-watershed, ignoring the initial detention effect and its later release in an exponential manner as exhibited by the actual watershed, due to surface roughness.

Therefore, to evaluate the performance of the rational method either the actual hydrologic data over a number of small urban watersheds for various number of storm events should be available; alternatively, one may generate such data set using hypothetical approach of runoff generation based on a physically based mathematical model applied on a number of hypothetical watersheds of varying sizes suitable for the application of the rational method. Considering the form of the IUH, it is surmised that the rational method is ideally suitable for application to a first order watershed to evaluate the runoff hydrograph at its outlet. In this study, the second approach of hypothetical rainfallrunoff generation procedure is adopted. A similar study approach, but rainfall-runoff data collected using small laboratory watersheds, was made by Xiong et al. ${ }^{4}$ (to evaluate the performance of a conceptual model based on non-linear reservoir concept widely used in 
Australian hydrological practices. Xiong et al. ${ }^{4}$ study proved that the runoff generated using kinematic wave theory was able to reproduce the actual runoff observed from small $\mathrm{V}$-watersheds for a number of uniform rate inputs. Taking all from the study results of Xiong et al. ${ }^{4}$ it is proposed in this study to generate runoff hydrographs, akin to the actual hydrographs, using the kinematic wave model on 10 hypothetical $\mathrm{V}$-watersheds of different sizes of area varying from $0.1 \mathrm{~km}^{2}$ (10 hectares) to $1 \mathrm{~km}^{2}$ (100 hectares).

\section{Estimation of time of concentration}

The time of concentration, Tc is generally defined as the time required for a drop of water to travel from the most hydrologically remote point in the catchment to the outlet point. There are hundreds of formulas available in the literature for the determination of Tc. For the study made herein the time of concentration formulas developed by Wong $^{5}$ were used. His studies were specially conducted for Kinematic wave model applied on V-catchments very well suits to this study.

\section{Test run details}

A total of 40 number of hypothetical test runs were made for runoff generation from $\mathrm{V}$-watersheds. The roughness of the overland flow plane considered was 0.042 ; and the roughness of the first order stream channel considered was 0.02 . The slope of the overland flow plane was considered as 0.045 and that of the first order channel was 0.0012 .

\section{Performance evaluation: nash sutcliffe criterion}

The closeness of reproduction of the benchmark solution (i.e., the Kinematic wave model solution) by the rational method was evaluated using the well known Nash-Sutcliffe efficiency criterion. ${ }^{6}$ It is expressed as:

Nash-Sutcliffe Efficiency in \%

$$
\eta=\left(1-\frac{\sum_{i=1}^{n}\left(Q_{o}-Q_{c}\right)^{2}}{\sum_{i=1}^{n}\left(Q_{o}-Q_{m}\right)^{2}}\right) * 100
$$

Where, $Q_{0}=$ Observed flow (Kinematic flow) at time t.

$\mathrm{Q}_{\mathrm{c}}=$ Computed flow (Clark, Nash flow) value at time $\mathrm{t}$.

$\mathrm{Q}_{\mathrm{m}}=$ Mean of observed values.

\section{Results and discussion}

The simulation of runoff using the well known kinematic wave model was made using the option available in HEC-HMS model. ${ }^{3}$ All the simulations were done for one minute time interval. Evaluations of the performance of the rational method to reproduce the solution of the kinematic wave model, considered as the benchmark model, were carried out by studying the ability to reproduce the overall shape of the hydrograph of the kinematic wave model. Useful evaluation results may be arrived at by studying a systematic variation of the uniform rainfall rates applied over the V-watersheds having constant watershed characteristics such as the roughness and slope of the overland flow planes and the V-channel of the V-watershed. Tables 1-4 show the pertinent characteristics of the simulation results of the $\mathrm{V}$-watersheds for varying rainfall rates. As the kinematic wave model is developed based on basic equations governing the one-dimensional flow movement on overland flow planes and routing along the first order channel of the V-watershed, the simulated results would be more realistic than that of the rational method. Accordingly, the initial runoff may rise slowly after satisfying the detention storage formed due to catchment runoff, while the rational method does not take into account the detention storage. However, after satisfying the detention storage, the kinematic wave model may translate the flow in a way similar to that of the rational method. The hydrographs may overlap with each other upto certain period in the recession limb of the hydrographs of both models. Thereafter, the hydrograph of the kinematic wave model may deviate away from that of the rational method due to release of the catchment storage formed initially as detention storage.

The results shown in Table 1-4 exhibit these details of detention storage developed, the rate of detention storage per unit depth of rainfall, the time at which both the kinematic wave hydrograph and the rational method hydrograph coincide on the rising limb of the hydrograph; the overall reproduction of the kinematic wave hydrograph by the rational method evaluated using the NashSutcliffe efficiency criterion and the time of concentration estimated for each watershed. A careful perusal of these tables reveals that the rate of detention storage per unit depth of rainfall increases with the increasing size of the catchment, but decreases with increasing rate of rainfall. The Nash-Sutcliffe efficiency (N-S $\eta$ (in \%)) decreases with the increasing size of the catchment, but increases for the same area with increasing rate of rainfall, though the increase may be marginal. The N-S $\eta$ (in \%) assessed for the size of watershed of $0.1 \mathrm{~km}^{2}$ was found to be nearly $90 \%$ and for the watershed area of $1 \mathrm{~km}^{2}$ it was found to be nearly $83 \%$. It may be inferred from this variation that the hydrograph of the kinematic wave model may be closely reproduced by the rational method when the watershed area is small and the reproduction capability decreases when the watershed area size increases, thus, confirming the usual notion that the rational method is applicable for small watersheds. One may consider that even $90 \% \mathrm{~N}-\mathrm{S} \eta$ (in \%) may not be considered as a good reproduction. But considering the limitation that the rational method is based on linear theory and developed with no consideration of catchments roughness and, therefore, it may not be able to reproduce a benchmark hydrograph of a model based on nonlinear theory which is capable of taking into account the detention storage. Based on the results shown in Table 1-4 one may consider that for practical purposes upto $85 \%$ of $\mathrm{N}-\mathrm{S} \eta$ (in \%) in reproducing the kinematic wave model by the rational method may be acceptable as good reproduction. This acceptable efficiency indicates a watershed area of $0.8 \mathrm{Km}^{2}$ (i.e. 80 hectares) suitable for applying the rational method.

As far as the peak rate of runoff hydrograph is concerned, both the kinematic wave theory and the rational method should theoretically produce the same peak discharge hydrograph. For the case of kinematic wave theory based runoff generation method, the peak runoff rate occurs at the time of equilibrium which is estimated same as that of the time of concentration. For the case of rational method, also the peak runoff occurs at the time of concentration of the watershed. The same inference is exhibited in the results shown in Table 1-4. The decreasing rate of detention storage per unit depth of rainfall for 
increasing rate of rainfall suggest that the kinematic wave hydrograph behaviour is more close to that of rational method hydrograph. Under this condition the time of concentration of the simulated hydrograph also decreases, thus, enabling the applicability of the rational method more suitable for such increasing rainfall rates. Figures $1 \&$ Figure 2 describe the kinematic wave hydrographs generated for two different sizes of watershed area $\left(A=0.1 \mathrm{Km}^{2}\right.$ and $\left.0.4 \mathrm{Km}^{2}\right)$, respectively) for the considered four rainfall rates. Theses figures clearly bring out that the generated hydrographs for higher rate of rainfall are more closely representing the behaviour of the triangular hydrograph of the rational method. Minshall ${ }^{7}$ in his study of a small experimental watershed (area $\left.=0.11 \mathrm{Km}^{2}\right)$ showed such behaviour of the hydrographs. ${ }^{8-13}$

Table I Persistent characteristics for varying areas between $0 . \mathrm{I} \mathrm{km}^{2}$ and $\mathrm{Ikm}^{2}$ for $\mathrm{i}=\mathrm{Icm} / \mathrm{hr}, \mathrm{Sc}=0.00 \mathrm{I}$, So $=0.045, \mathrm{nc}=0.02$ and $\mathrm{no}=0.042$

\begin{tabular}{|c|c|c|c|c|c|c|c|}
\hline $\begin{array}{l}\text { SI. } \\
\text { No. }\end{array}$ & $\begin{array}{l}\text { Area } \\
\left(K_{m^{2}}\right)\end{array}$ & $\begin{array}{l}\text { Rainfall } \\
(\mathrm{Cm} / \mathrm{hr})\end{array}$ & $\begin{array}{l}\text { Detention } \\
\text { storage } \\
\left(\mathrm{m}^{3}\right)\end{array}$ & $\begin{array}{l}\text { Detention storage } \\
\text { for unit rainfall }\left(\mathbf{m}^{3}\right)\end{array}$ & $\begin{array}{l}\text { Nash sutcliffe } \\
\text { efficiency (\%) }\end{array}$ & $\begin{array}{l}\text { Time when both hydrographs } \\
\text { unite in the rising limb(Mins) }\end{array}$ & Tc (Mins) \\
\hline 1 & 0.1 & 1 & 65.4 & 65.4 & 90.45 & 23 & 29 \\
\hline 2 & 0.2 & 1 & 159.2 & 159.2 & 90.39 & 27 & 35 \\
\hline 3 & 0.3 & I & 267.2 & 267.2 & 89.65 & 30 & 39 \\
\hline 4 & 0.4 & I & 391.1 & 391.1 & 88.33 & 32 & 42 \\
\hline 5 & 0.5 & 1 & 538.6 & 538.6 & 87.3 & 35 & 44 \\
\hline 6 & 0.6 & I & 654.6 & 651.6 & 86.67 & 36 & 17 \\
\hline 7 & 0.7 & 1 & 833.5 & 833.5 & 86.12 & 38 & 48 \\
\hline 8 & 0.8 & I & 980.9 & 980.9 & 84.91 & 39 & 50 \\
\hline 9 & 0.9 & 1 & 1122.1 & 1122.1 & 84.2 & 40 & 52 \\
\hline 10 & 1 & I & 1313.5 & 1313.5 & 82.57 & 12 & 53 \\
\hline
\end{tabular}

Table 2 Persistent characteristics for varying areas between $0 . \mathrm{lkm}^{2}$ and $\mathrm{I} \mathrm{km}^{2}$ for $\mathrm{i}=2 \mathrm{~cm} / \mathrm{hr}, \mathrm{Sc}=0.00 \mathrm{I} 2$, So $=0.045, \mathrm{nc}=0.02$ and no $=0.042$

\begin{tabular}{llllllll}
\hline SI.No & $\begin{array}{l}\text { Area } \\
\left(\mathbf{K m}^{2}\right)\end{array}$ & $\begin{array}{l}\text { Rainfall } \\
(\mathbf{c m} / \mathbf{h r})\end{array}$ & $\begin{array}{l}\text { Detention } \\
\text { storage } \\
\left(\mathbf{m}^{3}\right)\end{array}$ & $\begin{array}{l}\text { Detention storage } \\
\left.\text { for unit rainfall } \mathbf{( m}^{3}\right)\end{array}$ & $\begin{array}{l}\text { Nash sutcliffe } \\
\text { efficiency }(\%)\end{array}$ & $\begin{array}{l}\text { Time when both hydrographs } \\
\text { unite in the rising limb (Mins) }\end{array}$ & $\begin{array}{l}\text { Tc } \\
(\mathbf{M i n s})\end{array}$ \\
\hline 1 & 0.1 & 2 & 108 & 54 & 90.94 & 18 & 27 \\
2 & 0.2 & 2 & 253.2 & 126.6 & 90.55 & 21 & 27 \\
3 & 0.3 & 2 & 430.1 & 215.1 & 89.71 & 23 & 30 \\
4 & 0.4 & 2 & 602.8 & 301.4 & 88.8 & 25 & 33 \\
5 & 0.5 & 2 & 808.8 & 404.4 & 87.95 & 26 & 35 \\
6 & 0.6 & 2 & 1072 & 536 & 86.31 & 27 & 36 \\
7 & 0.7 & 2 & 1272 & 636 & 85.41 & 29 & 38 \\
8 & 0.8 & 2 & 1517 & 773.5 & 84.94 & 31 & 39 \\
9 & 0.9 & 2 & 1732 & 866 & 83.38 & 31 & 41 \\
10 & 1.0 & 2 & 2006 & 1003 & 82.95 & 32 & 12 \\
\hline
\end{tabular}

Table 3 Persistent characteristics for varying areas between $0.1 \mathrm{~km} 2$ and $\mathrm{I} \mathrm{km} 2$ for $\mathrm{i}=3 \mathrm{lcm} / \mathrm{hr}, \mathrm{Sc}=0.00 \mathrm{I} 2$, So $=0.045, \mathrm{nc}=0.02$ and $\mathrm{no}=0.042$

\begin{tabular}{llllllll}
\hline $\begin{array}{l}\text { S } \\
\text { I.No }\end{array}$ & $\begin{array}{l}\text { Area } \\
\left(\mathbf{K m}^{2}\right)\end{array}$ & $\begin{array}{l}\text { Rainfall } \\
(\mathbf{C m} / \text { lir) }\end{array}$ & $\begin{array}{l}\text { Detention } \\
\text { storage } \\
\left(\mathbf{m}^{3}\right)\end{array}$ & $\begin{array}{l}\text { Detention storage } \\
\left.\text { for unit rainfall } \mathbf{( m}^{3}\right)\end{array}$ & $\begin{array}{l}\text { Nash } \\
\text { sutcliffe } \\
\text { efficiency }\end{array}$ & $\begin{array}{l}\text { Time when both hydrographs } \\
\text { unite in the rising limb (Mins) }\end{array}$ & \begin{tabular}{l} 
Tc (Mins) \\
\hline 1
\end{tabular} \\
0.1 & 3 & 140.3 & 46.8 & 91 & 16 & 19 \\
2 & 0.2 & 3 & 340.7 & 113.6 & 90.1 & 19 & 23 \\
3 & 0.3 & 3 & 555.8 & 185.3 & 89.75 & 21 & 26 \\
4 & 0.1 & 3 & 814.9 & 271.6 & 89.36 & 22 & 28 \\
5 & 0.5 & 3 & 1076 & 358.7 & 88.25 & 23 & 30 \\
6 & 0.6 & 3 & 1412 & 470.7 & 86.8 & 25 & 31 \\
7 & 0.7 & 3 & 1647 & 549 & 86.05 & 25 & 33 \\
8 & 0.8 & 3 & 1993 & 664.3 & 84.45 & 26 & 34 \\
9 & 0.9 & 3 & 2331 & 777 & 84.15 & 27 & 35 \\
10 & 1 & 3 & 2678 & 892.7 & 83.01 & 28 & 36 \\
\hline
\end{tabular}


Table 4 Persistent characteristics for varying areas between $0.1 \mathrm{~km}^{2}$ and $\mathrm{I} \mathrm{km}^{2}$ for $\mathrm{i}=4 \mathrm{~cm} / \mathrm{hr}, \mathrm{Sc}=0.00 \mathrm{I} 2, \mathrm{So}=0.045$, $\mathrm{nc}=0.02$ and $\mathrm{no}=0.042$

\begin{tabular}{|c|c|c|c|c|c|c|c|}
\hline SI.No & $\begin{array}{l}\text { Area } \\
\left(\mathrm{Km}^{2}\right)\end{array}$ & $\begin{array}{l}\text { Rainfall } \\
(\mathrm{cm} / \mathrm{hr})\end{array}$ & $\begin{array}{l}\text { Detention } \\
\text { storage }\left(\mathrm{m}^{3}\right)\end{array}$ & $\begin{array}{l}\text { Detention storage } \\
\text { for unit rainfall }\left(\mathrm{m}^{3}\right)\end{array}$ & $\begin{array}{l}\text { Nash sutcliffe } \\
\text { efficiency (\%) }\end{array}$ & $\begin{array}{l}\text { Time when both hydrog,raphs } \\
\text { unite in the rising limb (Mins) }\end{array}$ & $\begin{array}{l}\text { Tc } \\
\text { (Mins) }\end{array}$ \\
\hline 1 & 0.1 & 4 & 174.4 & 43.6 & 91.33 & 15 & 17 \\
\hline 2 & 0.2 & 4 & 398.2 & 99.6 & 90.59 & 17 & 21 \\
\hline 3 & 0.3 & 4 & 704.3 & I76.I & 90.77 & 19 & 23 \\
\hline 4 & 0.4 & 4 & 1009 & 252.3 & 89.63 & 20 & 25 \\
\hline 5 & 0.5 & 4 & 1309 & 327.3 & 88.92 & 21 & 27 \\
\hline 6 & 0.6 & 4 & 1704 & 426 & 87.27 & 23 & 28 \\
\hline 7 & 0.7 & 4 & 1965 & 491.3 & 86.91 & 23 & 30 \\
\hline 8 & 0.8 & 4 & 2354 & 588.5 & 85.96 & 24 & 31 \\
\hline 9 & 0.9 & 4 & 2745 & 686.3 & 84.78 & 24 & 32 \\
\hline 10 & I & 4 & 3136 & 784 & 83.88 & 25 & 33 \\
\hline
\end{tabular}

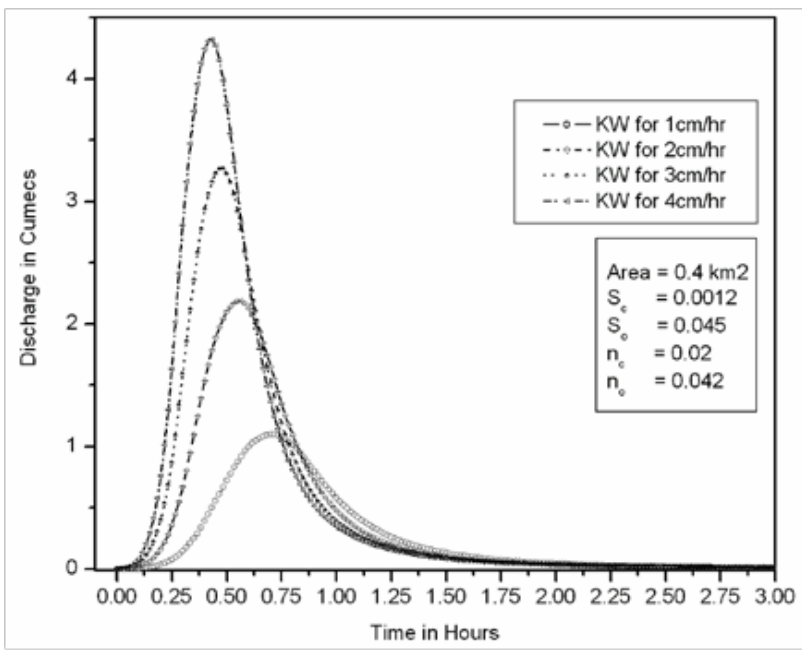

Figure I Kinematic wave hydrographs generated for $0 . \mathrm{km}^{2}$ area for increasing rainfall rates.

\section{Conclusion}

The study aimed at assessing the suitability of the rational method for runoff generation in small urban watersheds not only for assessing the peak flow estimation, but also for the suitability of the triangular runoff hydrograph generated by the rational method for simulating the actual runoff hydrograph. The study based on hypothetical rainfallrunoff generation approach based on kinematic wave theory clearly demonstrates that for small urban urban watersheds, approximated represented as symmetrical V-watersheds, the runoff hydrograph generated by the rational method, including the peak of the runoff, may be considered close to the kinematic wave model hydrograph, considered akin to that of the actual watershed runoff. Considering the limitations of the rational method and an acceptable Nash-Sutcliffe efficiency criterion of reproduction of over $85 \%$, it is surmised that the rational method may be appropriate for runoff estimation in small urban watersheds of area upto 80 hectares for design uniform rainfall rates up to $4 \mathrm{~cm} / \mathrm{hr}$.

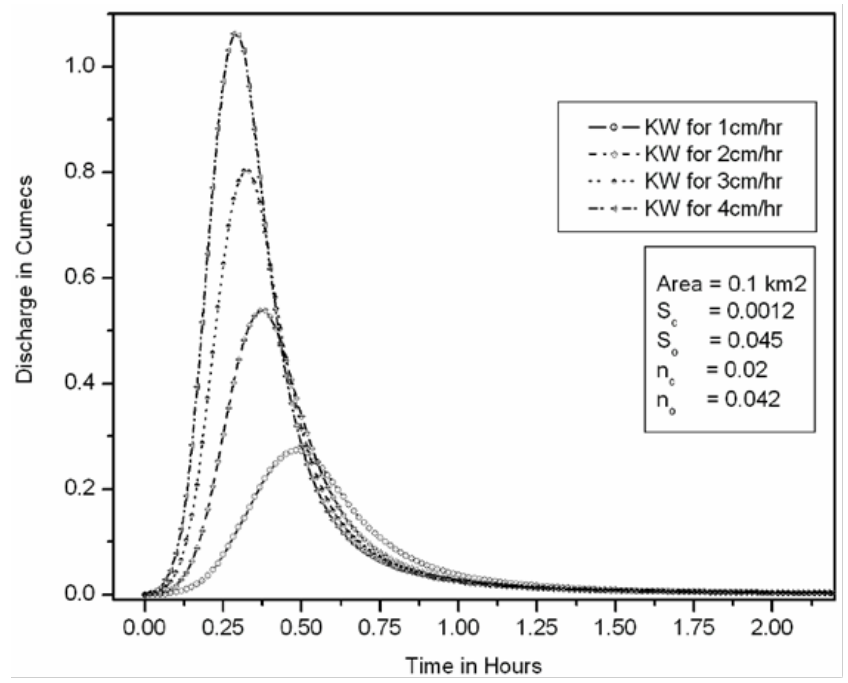

Figure 2 Kinematic wave hydrographs generated for $0.4 \mathrm{~km} 2$ area for increasing rainfall rates.

\section{Acknowledgment}

The guidance and support provided by Dr. M Perumal, Professor, Department of Hydrology, IIT Roorkee is highly acknowledged.

\section{Conflicts of interests}

The Author declares that there are no conflicts of interest.

\section{References}

1. Dooge JCI. Linear theory of hydrologic systems. Technical Bulletin, 1468 US Department of Agriculture, Washington, DC. 1973;327.

2. Nash JE. Determining runoff from rainfall. In: Proc. Institution of Civil Engineers. 1958;10:163-184.

3. USACE. Hydrologic Modeling System, HEC-HMS v3.3 User's Manual. US Army Corps of Engineers, Hydrologic Engineering Center. 2008.

4. Xiong Y, Melching CS. Comparison of kinematic-wave and nonlinear reservoir routing of urban watershed runoff. J Hydro Engg, ASCE. 2005;10(1):39-49. 
5. Wong TSW. Kinematic wave method for storm drainage design. in water encyclopedia: Surface and Agricultural water. In: Lehr JH, Keeley J, Editors. John Wiley, Ostrander, Ohio, USA. 2005;242-245.

6. Nash JE, Sutcliffe JV. River flow forecasting through conceptual models. Part 1-A discussion of principles: Journal of Hydrology. 1970;10(3):282290.

7. Minshall NE. Predicting storm runoff on small experimental watersheds. J Hydr Div ASCE. 1960;86(HY8):17-38.

8. Guo James CY. Rational hydrograph method for small urban watersheds. J Hydrol Engg. 2001;6(4):352-356.
9. Hack JT. Studies of longitudinal stream profiles in Virginia and Maryland. US Geol Survey Prof paper 294-B. 1957;45-97.

10. Roth G, Barbera PL, Greco M. On the description of the basin effective drainage structure. J Hydrol. 1995;187(1-2):119-135.

11. Singh VP. Hydrologic systems: Rainfall-runoff modeling. Prentice-Hall, Englewood Cliffs, NJ. 1988.

12. Singh VP. Kinematic Wave Modeling in Water Resources: Surface Water Hydrology. John Wiley and Sons, New York. 1996.

13. USACE. Hydrologic modeling system HEC-HMS Technical Reference Manual. Davis, California. 2000;157. 